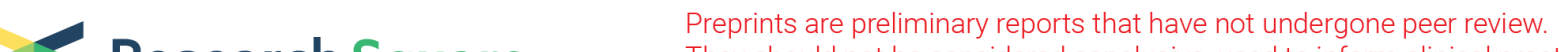 Research Square They should not be considered conclusive, used to inform clinical practice, or referenced by the media as validated information.
}

\section{Comparative Growth Performance of Kuroiler and Nigerian Indigenous Naked Neck Chickens Kept in a Tropical Environment}

ODAH EMMANUEL OKOLI ( $\square$ emmanuelodah22@gmail.com )

Federal University Wukari, Nigeria. https://orcid.org/0000-0002-7695-0665

Wheto Mathew

Federal University of Agriculture Abeokuta

Ojaowo Henry Temitope

Federal University of Agriculture Abeokuta

Obanla Fisayo Gideon

Federal University of Agriculture Abeokuta

Adebambo Oluwafunmilayo Ayoka

Federal University of Agriculture Abeokuta

Adebambo Ayotunde Olutumininu

Federal University of Agriculture Abeokuta

\section{Research Article}

Keywords: Comparative, growth performance, Kuroiler and Nigerian indigenous naked neck chickens

Posted Date: November 29th, 2021

DOI: https://doi.org/10.21203/rs.3.rs-983445/v1

License: (c) (i) This work is licensed under a Creative Commons Attribution 4.0 International License. Read Full License 


\section{Abstract}

Chicken production is an essential venture for steady household income generation, poverty alleviation and provision of quality nutritional aids. This study was conducted to compare growth performance of Kuroiler and Nigerian indigenous naked neck chickens reared in the tropics. A total of 538 birds comprising 345 indigenous Nigerian naked neck and 193 Kuroiler chickens genotypes were sampled. Body weight and linear body measurements were observed at 2, 4, 6, 8 and 10th week. Data obtained were subjected to 2-way analysis of variance using GLM procedure of SAS. There exist significant variations in chicken genotype with growth performance. Kuroiler birds significantly showed heavier mean body weight $(p<0.05)$ at various critical growth stages observed than the Nigerian indigenous naked neck chickens reared under same conditions. The influence of genotype and sex on mean body weight and breast girth measures of chickens remain insignificant throughout early growth stages. However, at 6th, 8th and 10th week of age, Kuroiler breeds demonstrated superior growth rate and performance response compared to Nigerian indigenous naked neck fowls. Both chicken breeds exhibited differential growth patterns and sexual dimorphism in favour of male populations. Introduction and crossing of Kuroiler strains with Nigerian indigenous naked neck birds might result in better performance and adaptability.

\section{Introduction}

Chicken constitute a unique and vital component of the global animal genetic resources. Chicken production has become a globally accepted practice appraised for regular household income generation, rural poverty alleviation and provision of quality nutritional aids for human needs, sustenance and industrial uses. The current demand for available animal-based protein sources will double progressively in the coming years due to rising human population. Poultry products especially chicken derivatives are common and the most affordable animal protein sources in developed and developing regions worldwide. Chickens are recognized as valuable component of global genetic resources (Ogbu, 2021), and the most widely distributed avian specie in the Nigerian poultry production industry with a total population size of 180 million birds (FAOSTAT, 2019). Several studies have x-rayed growth and compared the growth performance of different indigenous and exotic farm animal species including chickens (Malpotra et al., 2018; Mueller et al., 2020), rabbits (Gasco et al., 2019), sheep and goats (Yashim, et al., 2016; Worku et al., 2019) and Cattle, (Denis et al., 2019).

According to Lawrence and Fowler, (2002) growth describes an increase in the number of cells or body size per unit time. Growth in chicken is a complex trait believed to be influenced by genetic and nongenetic factors as: genotype, sex, breeds, nutrition, adaptability and management profile. Indigenous fowls unlike the exotic breed exhibits sigmoid growth (Ismail, 1997). This growth pattern is also associated with Nigerian indigenous naked neck chickens.

The naked neck chickens represent a breed of birds naturally devoid of feather coverage on the neck and vent region. Naked neck trait results from an autosomal gene in chicken (Warren, 1933) and controlled by 
an incompletely dominant allele located near the middle of chromosome 3 (Duodo, 2013). Indigenous Nigeria naked neck chickens are possess robust adaptability and can thrive efficiently in the tropics and hot humid zones. They are distributed in rural areas, reared by the majority of the rural poor (Ogbu, 2021). Keeping naked neck birds under warm and hot humid areas support the attainment of bird's growth potential, body weight and egg production (Galal and Fathi, 2001). The growth rate and production level of Nigerian indigenous chickens are quite slow relative to exotic strains under similar conditions. An insight into understanding the genetic variation of these useful breeds becomes imperative to identify populations with superior merit. This study therefore focus on comparative evaluation of growth performance of Kuroiler and Nigerian indigenous naked neck chickens.

\section{Methodology}

This study was carried out at the Programme for Emerging Agricultural Research Leadership poultry building unit of the Directorate of University Farms of Federal University of Agriculture Abeokuta, Nigeria. Characterized by tropical rainforest vegetation, mean temperature of $33.7^{\circ} \mathrm{C}$, relative humidity of $80 \%$, rainfall of about $1037 \mathrm{~mm}$ and altitude $76 \mathrm{~mm}$ above sea, the area lies within latitude $7^{\circ} 13^{\prime}, 49^{\circ} 46^{\prime} \mathrm{N}$, longitude $3^{\circ} 26^{\prime}, 11^{\circ} 98^{\prime} \mathrm{E}$ (Goggle Earth, 2018). Eggs from parent stock Kuroiler and naked neck chickens were collected at the poultry breeding unit and hatched for this experiment. A total of 538 birds comprising 345 Nigerian indigenous naked neck and 193 Kuroiler chickens genotypes were sampled. Body weight and linear body measurements (breast girth) were observed at $2^{\text {nd }}, 4^{\text {th }}, 6^{\text {th }}, 8^{\text {th }}$ and $10^{\text {th }}$ week using sensitive weighing scale (grams) and graduated measuring tapes (centimeters) respectively. Data obtained on body weight and morphometric trait was subjected to two way analysis of variance (ANOVA) using general linear model (GLM) procedure of SAS 9.2 software (SAS, 2010, SAS Institute Inc. Cary, North Carolina, USA). Significant differences were separated using turkey-Kramer.

\section{Results And Discussion}

\section{Effect of genotype on chicken growth trait}

Table 1 shows the effect of chicken genotypes on growth traits. There exist significant variations in genotype with chicken growth. Kuroiler birds sustain significantly higher mean body weight $(p<0.05)$ at various critical growth stages than naked neck chicken reared under same conditions. At $10^{\text {th }}$ week of growth, Kuroiler birds attain highest $\left(959.72 \pm 0.07^{\mathrm{a}}\right)$ mean body weight compared to Nigerian indigenous naked neck chicken $\left(623.69 \pm 12.32^{\mathrm{b}}\right)$ at same age. The influence of chicken genotype on breast girth remains insignificant during early growth stages. However, as birds approaches $10^{\text {th }}$ week, Kuroiler showed significantly higher mean breast girth $\left(26.80 \pm 0.23^{a}\right)$ than naked neck chicken $\left(20.51 \pm 0.18^{b}\right)$.

\section{Table1. Effect of chicken genotype on growth trait}




\begin{tabular}{cclcc}
\hline Wk & N & Genotype & BG $(\mathrm{cm})$ & BWT $(\mathrm{g})$ \\
\hline 2 & 532 & KLR & $18.95 \pm 3.98$ & $154.42 \pm 2.0^{\mathrm{a}}$ \\
& & NKN & $11.64 \pm 0.11$ & $127.65 \pm 6.21^{\mathrm{b}}$ \\
\multirow{2}{*}{5} & 529 & KLR & $17.46 \pm 0.15^{\mathrm{a}}$ & $396.45 \pm 5.60^{\mathrm{a}}$ \\
& & NKN & $14.37 \pm 0.12^{\mathrm{b}}$ & $220.27 \pm 7.48^{\mathrm{b}}$ \\
\multirow{2}{*}{6} & \multirow{2}{*}{512} & KLR & $20.97 \pm 0.16^{\mathrm{a}}$ & $614.19 \pm 8.26^{\mathrm{a}}$ \\
& \multirow{2}{*}{8} & NKN & $15.66 \pm 0.16^{\mathrm{b}}$ & $356.95 \pm 9.68^{\mathrm{b}}$ \\
& \multirow{2}{*}{503} & KLR & $23.65 \pm 0.20^{\mathrm{a}}$ & $800.57 \pm 19.50^{\mathrm{a}}$ \\
& \multirow{2}{*}{10} & NKN & $18.53 \pm 0.15^{\mathrm{b}}$ & $499.85 \pm 9.80^{\mathrm{b}}$ \\
& \multirow{2}{*}{496} & KLR & $26.80 \pm 0.23^{\mathrm{a}}$ & $959.72 \pm 0.07^{\mathrm{a}}$ \\
& & NKN & $20.51 \pm 0.18^{\mathrm{b}}$ & $623.69 \pm 12.32^{\mathrm{b}}$ \\
\hline
\end{tabular}

${ }^{a b c}$ Mean with different superscripts on the same column are significantly different $(p<0.05)$.

Wk=week, KLR=Kuroiler, NKN=Nigerian indigenous Naked neck, BG=Breast girth, BWT=body weight, $\mathrm{N}=$ Number of observations, $\mathrm{g}=$ grams and $\mathrm{Cm}=$ Centimeter.

\section{Effect of sex on chicken growth trait}

Table 2 presents the effect of sex on chicken growth parameters. Sex did not have significant effect on chicken growth traits at $2^{\text {nd }}$ and $4^{\text {th }}$ week. However, at $6^{\text {th }}, 8^{\text {th }}$ and $10^{\text {th }}$ week of age, the males were generally superior $(p<0.05)$ to females of both Kuroiler and Nigerian indigenous naked neck chickens in mean body weight and average breast girth measures subjected to same management profile.

\section{Table2. Effect of sex on chicken growth trait}

\begin{tabular}{|c|c|c|c|c|}
\hline $\mathrm{Wk}$ & $\mathrm{N}$ & $\operatorname{sex}$ & $\mathrm{BG}(\mathrm{Cm})$ & BWT (g) \\
\hline \multirow[t]{2}{*}{2} & 532 & b & $12.38 \pm 0.11$ & $143.99 \pm 2.38$ \\
\hline & & 9 & $18.20 \pm 4.40$ & $138.08 \pm 5.19$ \\
\hline \multirow[t]{2}{*}{4} & 529 & b & $16.03 \pm 0.17$ & $315.44 \pm 7.23$ \\
\hline & & q & $15.82 \pm 0.16$ & $301.27 \pm 8.60$ \\
\hline \multirow[t]{2}{*}{6} & 512 & 8 & $18.65 \pm 0.21^{\mathrm{a}}$ & $502.99 \pm 10.85^{\mathrm{a}}$ \\
\hline & & q & $17.98 \pm 0.23^{b}$ & $468.15 \pm 11.84^{b}$ \\
\hline \multirow[t]{2}{*}{8} & 503 & 8 & $21.58 \pm 0.22^{\mathrm{a}}$ & $691.05 \pm 18.97^{\mathrm{a}}$ \\
\hline & & q & $20.60 \pm 0.24^{b}$ & $609.38 \pm 18.61^{b}$ \\
\hline \multirow[t]{2}{*}{10} & 496 & 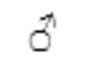 & $24.49 \pm 0.27^{\mathrm{a}}$ & $849.42 \pm 14.56^{\mathrm{a}}$ \\
\hline & & q & $22.82 \pm 0.29^{b}$ & $733.99 \pm 15.33^{b}$ \\
\hline
\end{tabular}

${ }^{a b c}$ Mean with different superscripts on the same column are significantly different $(p<0.05)$. 


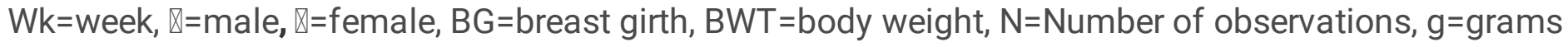
and $\mathrm{Cm}=$ Centimeter.

\section{Effect of Sex and Genotype interaction on chicken growth traits}

Table 3 show the effect of genotype and sex interaction on chicken growth parameters. Sex and chicken genotype combination showed no significance on early birds growth traits. When compared with respect to genotype and sex interactions, Kuroiler sexes differ significantly in breast size and body weight from naked neck sexes only at $8^{\text {th }}$ and $10^{\text {th }}$ weeks. At $8^{\text {th }}$ week, mean breast girth of Kuroiler sexes were statistically alike $\left(23.76 \pm 0.23^{\mathrm{a}}\right.$ and $\left.23.54 \pm 0.37^{\mathrm{a}}\right)$, similar observation was recorded for their mean body weight $\left(809.41 \pm 21.76^{\mathrm{a}}\right.$ and $\left.791.74 \pm 39.75^{\mathrm{a}}\right)$. Also, at $10^{\text {th }}$ week, both Kuroiler sexes weighed similar values $\left(982.60 \pm 14.22^{\mathrm{a}}\right.$ and $\left.936.85 \pm 16.57^{\mathrm{a}}\right)$ but significantly heavier than naked neck male and females.

\section{Table 3. Effect of sex and genotype interaction on chicken growth traits}

\begin{tabular}{|c|c|c|c|c|c|}
\hline Wk & $\mathrm{N}$ & Genotype & Sex & $\mathrm{BG}(\mathrm{Cm})$ & BWT (g) \\
\hline \multirow[t]{4}{*}{2} & \multirow[t]{4}{*}{532} & \multirow[t]{2}{*}{ KLR } & 8 & $12.94 \pm 0.13$ & $154.43 \pm 2.62$ \\
\hline & & & q & $24.97 \pm 12.23$ & $154.40 \pm 3.28$ \\
\hline & & \multirow{2}{*}{ NKN } & 8 & $11.83 \pm 0.15$ & $133.54 \pm 4.94$ \\
\hline & & & 우 & $11.44 \pm 0.13$ & $121.75 \pm 7.76$ \\
\hline \multirow{4}{*}{4} & \multirow{4}{*}{529} & \multirow{2}{*}{$\mathrm{KLR}$} & 8 & $17.55 \pm 0.22$ & $399.07 \pm 6.92$ \\
\hline & & & 우 & $17.37 \pm 0.19$ & $393.82 \pm 9.52$ \\
\hline & & \multirow{2}{*}{ NKN } & 8 & $14.69 \pm 0.18$ & $323.81 \pm 10.89$ \\
\hline & & & 우 & $14.09 \pm 0.15$ & $208.72 \pm 9.02$ \\
\hline \multirow{4}{*}{6} & \multirow{4}{*}{512} & \multirow{2}{*}{ KLR } & 8 & $21.05 \pm 0.20$ & $632.46 \pm 10.46$ \\
\hline & & & 우 & $20.89 \pm 0.27$ & $604.93 \pm 13.21$ \\
\hline & & \multirow{2}{*}{$\mathrm{NKN}$} & 8 & $16.25 \pm 0.34$ & $382.52 \pm 16.03$ \\
\hline & & & 우 & $15.08 \pm 0.18$ & $331.38 \pm 11.41$ \\
\hline \multirow{4}{*}{8} & \multirow{4}{*}{503} & \multirow{2}{*}{ KLR } & 8 & $23.76 \pm 0.23 \mathrm{a}$ & $809.41 \pm 21.76^{\mathrm{a}}$ \\
\hline & & & 우 & $23.54 \pm 0.37^{\mathrm{a}}$ & $791.74 \pm 39.75^{\mathrm{a}}$ \\
\hline & & \multirow{2}{*}{$\mathrm{NKN}$} & 8 & $19.41 \pm 0.24^{b}$ & $572.69 \pm 22.11^{b}$ \\
\hline & & & 우 & $17.67 \pm 0.17^{\mathrm{bc}}$ & $427.02 \pm 9.62^{b c}$ \\
\hline \multirow{4}{*}{10} & \multirow{4}{*}{496} & \multirow{3}{*}{ KLR } & 8 & $27.35 \pm 0.26$ & $982.60 \pm 14.22^{\mathrm{a}}$ \\
\hline & & & 우 & $26.26 \pm 0.47$ & $936.85 \pm 16.57^{a}$ \\
\hline & & & 8 & $21.63 \pm 0.34$ & $716.25 \pm 29.49^{b}$ \\
\hline & & NKN & 우 & $19.38 \pm 0.19$ & $531.15 \pm 11.71^{b c}$ \\
\hline
\end{tabular}

${ }^{a b c}$ Mean with different superscripts on the same column are significantly different $(p<0.05)$. 
Wk=week, KLR=Kuroiler, NKN = Nigerian indigenous Naked neck, $\nabla=$ male, $\nabla=$ female, $B G=$ Breast girth, BWT=body weight and $\mathrm{N}=$ number of observations, $\mathrm{g}=$ grams and $\mathrm{Cm}=$ Centimeter.

Growth in farm animals reflects a biological increase in an animal's size or mass over its lifetime. Superior growth performance of Kuroiler chicken breeds compared to Nigerian indigenous naked neck fowls observed in this study might be attributed to better genetic potential that exotic breeds have acquired over series of selection and multiple cross breeding have genetically improved their growth rate and production potentials. This reveals that the genetic constitution of Nigerian indigenous naked neck chickens is still intact has not yet undergone full gene mixing with exotic lines (Islam, 2009). The significant sex effect to on body weight and linear measurements at $6^{\text {th }}$ to $10^{\text {th }}$ week is in agreement with literature (Ajayi and Ejiofor, 2009). Heavier weight of male to female birds in this study is consistent with Odah et al. (2019) who also reported differential growth rate among indigenous chicken population of Bekwarra, Southern Nigeria. This result also agree favorably with previous reports of variation in growth pattern within species (Deeb and Lamont, 2002) and comparable with the findings of Ajayi and Ejiofor, (2009) for Ross and Anak Broiler Strains reared in the high rainforest zone of Nigeria and Madilindi et al., (2018) for broiler chickens kept in subtropical South Africa environment. Superior male weights in this report might resulted from better feed consumption abilities and high level of testosterone secretions in males' which influence growth dynamics of body parts not directly associated with muscles mass, reproduction and sexual development (Lawrence and Fowler, 2002).

Sexual dimorphism in favour of males observed in both genotypes in this report is consistent with Adeleke, (2005) and Isidahomen et al., (2012) who also revealed differential growth pattern in chickens. The difference observed in growth rate for Kuroiler and Nigerian indigenous naked neck chicken is an indication that there exist variation in their growth pattern, attributed to strain differences and birds genetics. High significant difference in genotype and sex interaction of Kuroiler breeds and Nigerian indigenous naked neck fowls agreed is inline with the reports of (Ajayi and Ejiofor, 2009; Razuki et al., 2011) who also observed significant genotype and sex interaction on body weight of Ross and Anak Broiler Strains. This however differ from the results of Ojedapo et al. (2008) who showed no significance in genotype and sex interaction on chicken body weight. The variations in mean body weight and breast girth measurements of chicken genotypes with age in this study can be attributed to genetic make-up, sexual dimorphism, age and bird physiology because organs and tissue functions determines general body development Adedeji et al. (2006).

In conclusion, the chickens exhibited differential growth patterns, attributable to genetic composition and strain differences. Kuroiler revealed superior growth rate and performance relative to Nigerian indigenous naked neck chickens. Introduction of Kuroiler strains and subsequent crossbreeding with Nigerian indigenous naked neck birds might improve their performance and adaptability.

\section{Declarations}


Acknowledgements; the authors wish to acknowledge the staff of Program for Emerging Agricultural Research Leadership (PEARL) Poultry Breeding Unit, Federal University of Agriculture, Abeokuta, Nigeria for their support and management of experiment birds.

Authors contribution; Author WM and AAO conceived and designed the study, OEO, OHT and OFG were involved in investigation, data collection and manuscript writing. Author AOA provided facilities, supports in data analysis and revising the manuscript.

Statement of Animal Rights; Protocols for the conduct of this research were approved by the Animal Care and Use Committee of the Federal University of Agriculture, Abeokuta, Nigeria.

Competing Interest: The authors have declared that no competing interest exists.

Availability of data and material; all relevant data and materials for this research shall be made available on reasonable request.

Compliance with ethical standards; the manuscript does not contain clinical studies or patient data.

Consent to participate; not applicable.

Consent for publication; Not applicable.

Funding; not applicable.

Code availability; Not applicable.

\section{References}

1. Adeleke, M.O. 2005. Genetic evaluation of improved indigenous and exotic crossbred chickens for growth and laying performance. M. Agric dissertation, University of Agriculture Abeokuta, Nigeria. Pp83.

2. Ajayi, F.O and Ejiofor, O. 2009. Effect of sex and genotype interaction on growth and some development characteristics of Ross and Anak broiler strains in the high rain forest zone of Nigeria. Asian Journal of Poultry science. 1-6.

3. Denis K., Tamara P., Vladimir T. Miroslav P., Igor J., Saša K. and Dragan S. 2019. Influence of Farm Management for Calves on Growth Performance and Meat Quality Traits Duration Fattening of Simmental Bulls and Heifers. Animals, Volume 9, 941; doi: 10.3390/ani9110941 www.mdpi.com/journal/animals.

4. FAOSTAT. 2019. Livestock Primary Production Data. http://faostat.fao.org

5. Galal, A. and Fathi, M. M., 2001. Improving carcass yield of chicken by introducing naked neck and frizzle genes under hot prevailing conditions. Egypt Poultry. Science. 21:339-362. 
6. Gasco, L., Dabbou, S., Trocino, A. 2019. Effect of dietary supplementation with insect fats on growth performance, digestive efficiency and health of rabbits. J Animal Sci Biotechnol 10, 4 (2019). https://doi.org/10.1186/s40104-018-0309-2.

7. Isidahomen, C.E., Ilori, B.M., \& Akano, K. (2012). Genetic and Sex Differences in Carcass Traits of Nigerian Indigenous Chickens. Journal of Animal Science Advances, 2, 637-648.

8. Islam, M.A. and Nishibori, M. 2009. Indigenous naked neck chicken: a valuable genetic resource for Bangladesh. World's Poultry Journal. Vol. 65: 125-139.

9. Ismail, M.A. 1997. Growth curve and inheritance of body weight prior to sexual maturity in indigenous chickens. Faculty of animal production University of Khartoum, 42-45.

10. Lawrence, T.L.J and Fowler, V.R. 2002 Growth of Farm Animals. $2^{\text {nd }}$ ed. CABI publishing, New York. ISBN 08519948491

11. Madilindi M. A., Mokobane. A., Letwaba M. A., Tshilate T. S., Banga. C. B., Rambau. M. D., Bhebhe. E and Benyi. K. 2018. Effects of sex and stocking density on the performance of broiler chickens in a subtropical environment. South African Journal of Animal Science 2018, 48 (No. 3) http://dx.doi.org/10.4314/sajas.v48i3.

12. Malpotra, K., Chahal, U., Aps, S., Singh, P. and Hundal, J. 2017. Growth Performance of Broiler Chicken as Affected by Phased Feed Restriction and Fat Supplementation. Indian Journal of Animal Nutrition. 34. 329. 10.5958/2231-6744.2017.00053.6.

13. Mueller, S., L. Taddei, D. Albiker, M. Kreuzer, M. Siegrist, R.E. Messikommer, I.D.M. Gangnat, 2020. Growth, carcass, and meat quality of 2 dual-purpose chickens and a layer hybrid grown for 67 or 84 D compared with slow-growing broilers, Journal of Applied Poultry Research, Volume 29, Issue 1, 2020, Pages 185-196. https://doi.org/10.1016/j.japr.2019.10.005.

14. Odah, E.O., Daikwo S.I., Mbap, S.T., Okpanachi, U. 2019. Phenotypic Characterization of Local Chickens (Gallus gallus domesticus) in Bekwarra Cross River State, Nigeria. JSM Vet Med Res 2: 7.

15. Ogbu C.C. 2021. Utilization and Conservation of Landrace Chickens of Nigeria: Physical and Performance Characteristics, Issues and Concerns, Landraces - Traditional Variety and Natural Breed, Amr Elkelish, IntechOpen, DOI: 10.5772/intechopen.96580. Available from: https://www.intechopen.com/chapters/75670

16. Ojedapo, L.O., Akinnokun, O., Adedeji, T.A., Olayeni, T.B., Ameen, S.A and Amao, S.R. 2008. Effect of strain and sex on carcass characteristics of three commercial broilers reared on deep litter system in the derived savannah area of Nigeria. World Journal of Agricultural Science. 4(4):487-491.

17. Razuki, W.M., Mukhlis, S.R., Jasim, F.H., and Hamad, R.F. 2011. Production performance of four broiler genotypes reared under high ambient temperature. International Journal of Poultry Science.10 (2)87-92.

18. SAS. 2010. Statistical Analysis System. Version 9.2 for windows, SAS Institute Incorporated Cary, North Carolina, USA.

19. Warren D.C. 1933. Nine independently inherited autosomal factors in the fowl. Genetics. 18: 68-81. 
20. Worku, A., Alemu, T., Gudeto, A. and Dadi, G. 2019. Growth performance evaluation of sheep breeds under farmers' management at Fentale District, Oromia Regional State, Ethiopia. 18-24.

21. Yashim, S.M., Adekola, S.T., Abdu, S. B., Gadzama, I.U and Hassan, M. R. (2016). Feed intake, Growth performance and Nutrient digestibility in growing Red Sokoto bucks fed diets containing graded levels of dried sweet orange peel meal. Animal Research International. 13(1): 2328 - 23372328 ISSN: $1597-3115$

\section{Figures}

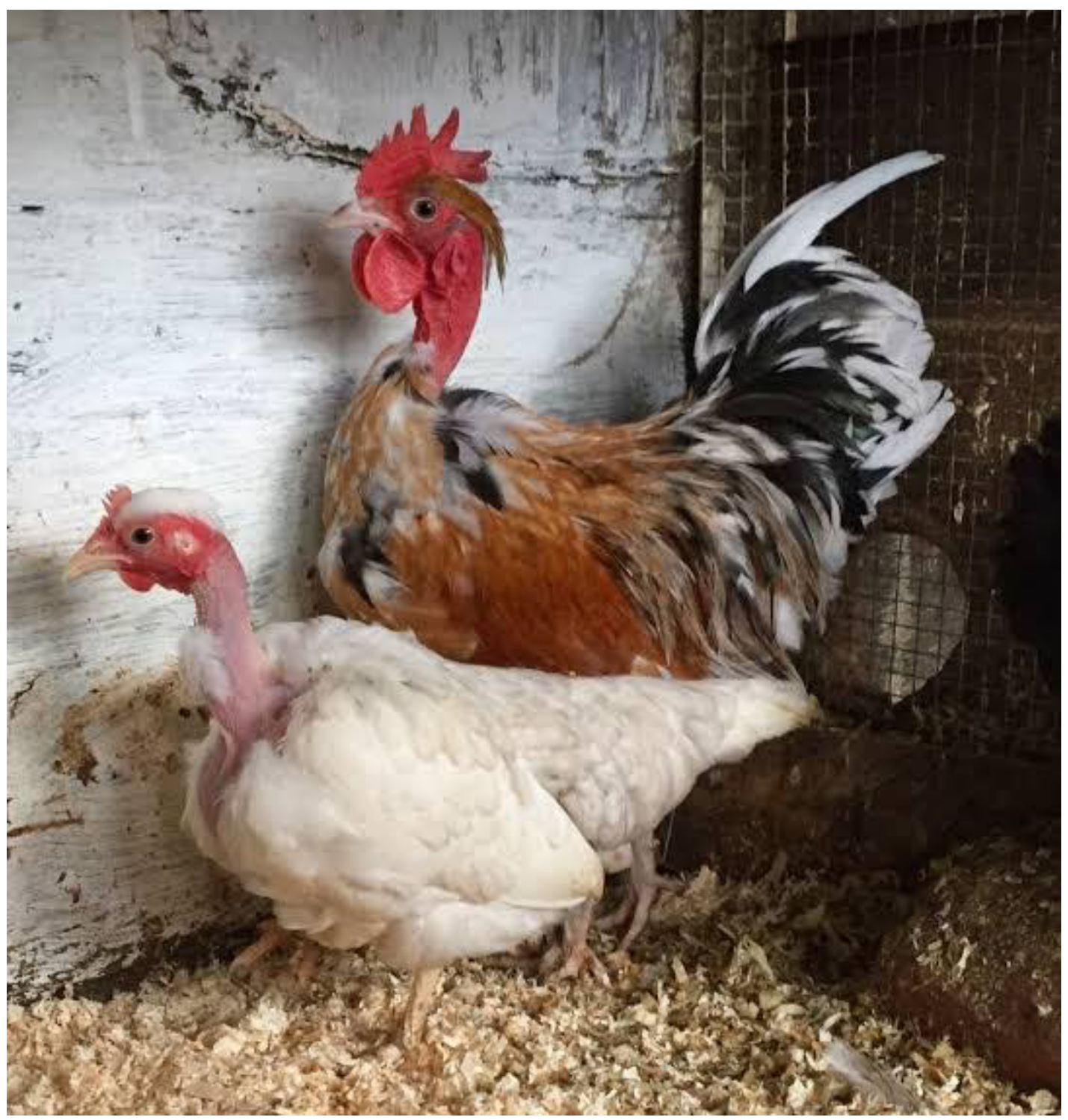

Figure 1

Nigerian indigenous naked neck cock and hen 


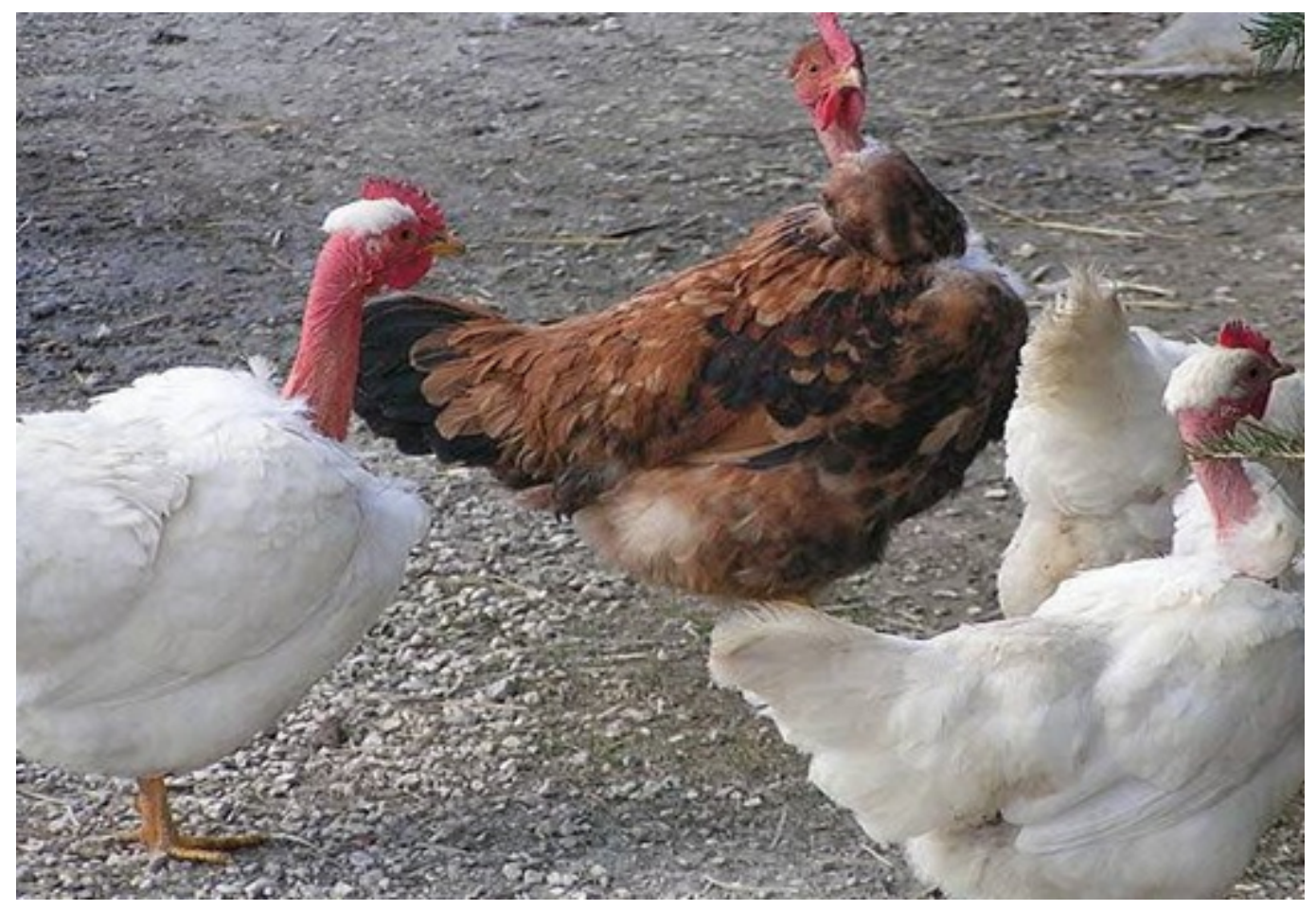

Figure 2

Nigerian indigenous naked neck hens

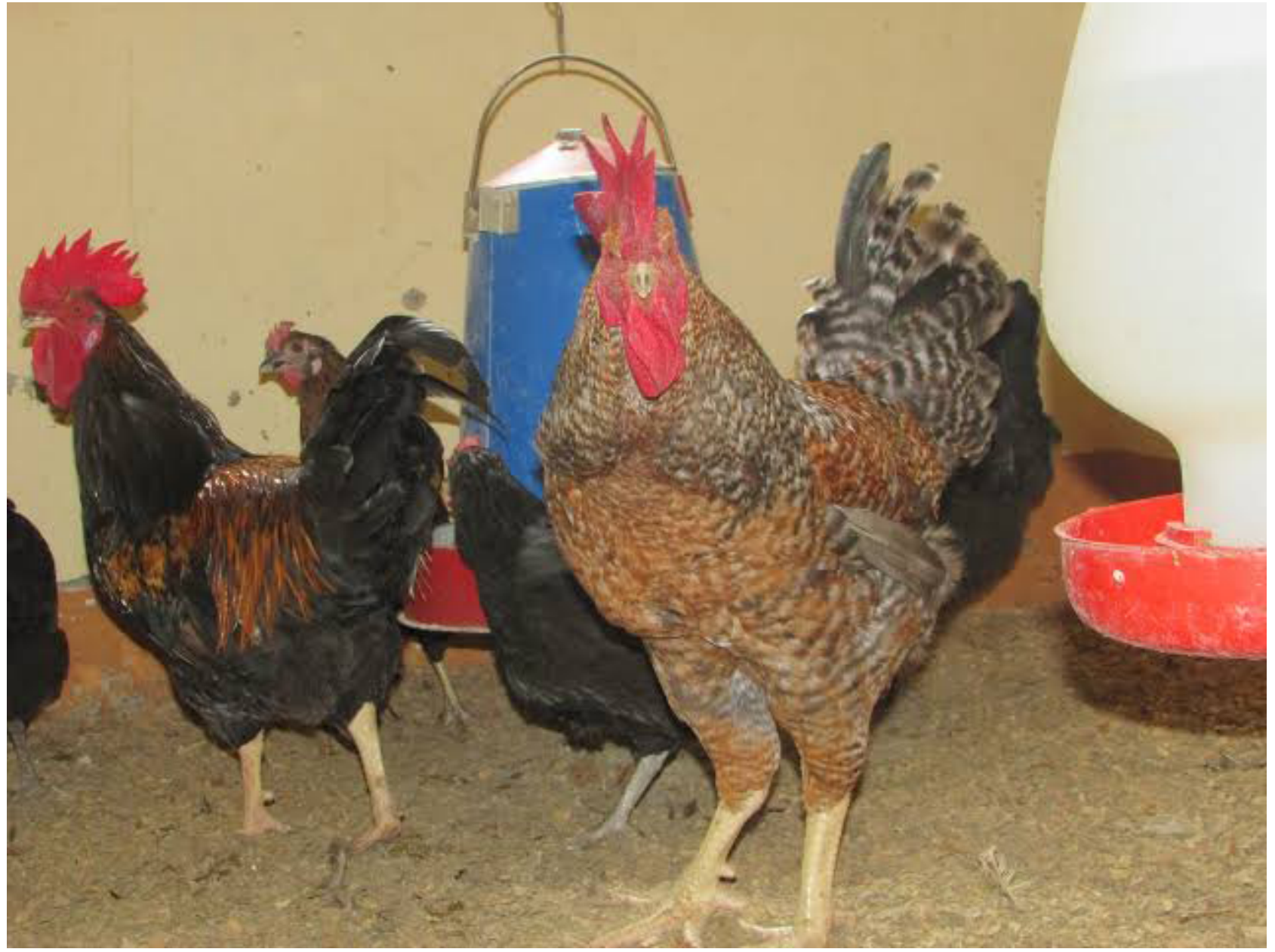


Figure 3

Kuroiler cocks.

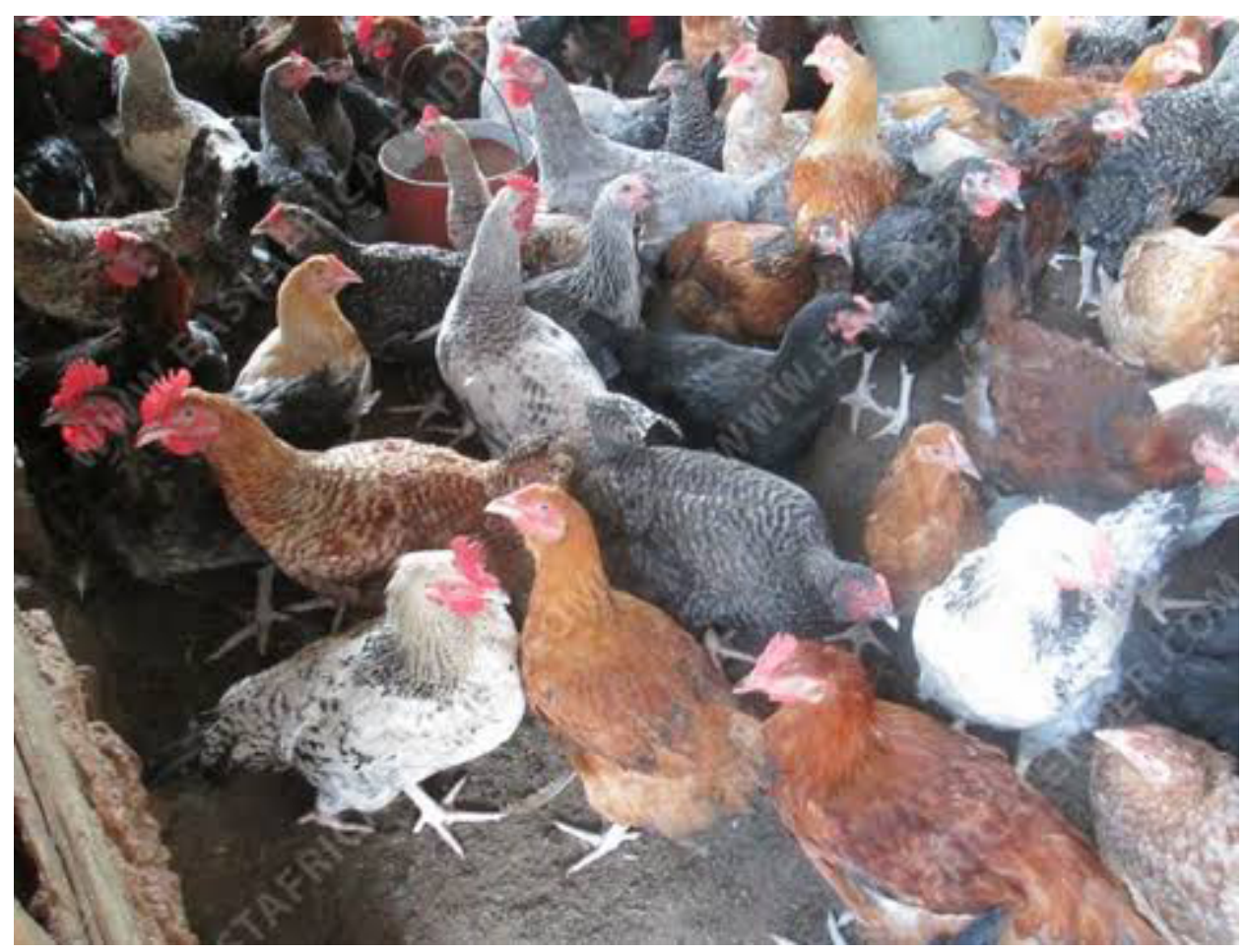

Figure 4

Kuroiler hens. 